\title{
Corrigendum: Patterns of diversification amongst tropical regions compared: a case study in Sapotaceae
}

\author{
Kate E. Armstrong 1, 2, 3*, Graham N. Stone ${ }^{2}$, James A. Nicholls ${ }^{2}$, Eugenio Valderrama ${ }^{2,3}$, \\ Arne A. Anderberg ${ }^{4}$, Jenny Smedmark ${ }^{5}$, Laurent Gautier ${ }^{6}$, Yamama Naciri ${ }^{6}$, \\ Richard Milne ${ }^{7}$ and James E. Richardson ${ }^{3,8}$ \\ ${ }^{1}$ The New York Botanical Garden, New York, NY, USA, ${ }^{2}$ Institute of Evolutionary Biology, University of Edinburgh, Edinburgh, \\ Scotland, ${ }^{3}$ Royal Botanic Garden Edinburgh, Edinburgh, Scotland, ${ }^{4}$ Naturhistoriska Riksmuseet, Stockholm, Sweden, \\ ${ }^{5}$ University Museum of Bergen, Bergen, Norway, ${ }^{6}$ Conservatoire et Jardin Botaniques, Genève, Switzerland, ${ }^{7}$ Institute of \\ Molecular Plant Sciences, University of Edinburgh, Edinburgh, Scotland, ${ }^{8}$ Laboratorio de Botánica y Sistemática, \\ Universidad de los Andes, Bogotá, Colombia
}

Keywords: Sapotaceae, Manilkara, pantropical, biogeography, diversification rates

\section{OPEN ACCESS}

Edited and reviewed by: Toby Pennington,

Royal Botanic Garden Edinburgh, UK

*Correspondence:

Kate E. Armstrong

karmstrong@nybg.org

Specialty section:

This article was submitted to Evolutionary and Population Genetics, a section of the journal Frontiers in

Genetics

Received: 23 January 2015 Accepted: 18 February 2015 Published: 05 March 2015

Citation: Armstrong KE, Stone GN, Nicholls JA, Valderrama $E$, Anderberg $A A$, Smedmark J, Gautier L, Naciri Y, Milne

$R$ and Richardson JE (2015)

Corrigendum: Patterns of diversification amongst tropical regions compared: a case study in Sapotaceae. Front. Genet. 6:86. doi: 10.3389/fgene.2015.00086

\section{A Corrigendum on}

Patterns of diversification amongst tropical regions compared: a case study in Sapotaceae by Armstrong, K. E., Stone, G. N., Nicholls, J. A., Valderrama, E., Anderberg, A. A., Smedmark, J., et al. (2014). Front. Genet. 5:362. doi: 10.3389/fgene.2014.00362

In the sixth paragraph of the Discussion section entitled "Regional Diversification in Manilkara," in the sentence beginning "In Sapotaceae four lineages of Isonandreae have migrated..." the citation of Swenson et al., 2008 should instead be: Swenson, U., Nylinder, S., and Munzinger, J. (2014). Sapotaceae biogeography supports New Caledonia being an old Darwinian island. J. Biogeogr. 41, 797-809. doi: 10.1111/jbi.12246

Additionally, in the second paragraph of the Supplementary Material section entitled "Evidence for Chloroplast Capture?" in the sentence beginning "The species Chrysophyllum cuneifolium is inferred to have originated..." the citation of Särkinen et al., 2007, should instead be: Swenson, U., Richardson, J. E., and Bartish, I. V. (2008). Multi-gene phylogeny of the pantropical subfamily Chrysophylloideae (Sapotaceae): evidence of generic polyphyly and extensive morphological homoplasy. Cladistics 24, 1006-1031. doi: 10.1111/j.1096-0031.2008.00235.x

Conflict of Interest Statement: The authors declare that the research was conducted in the absence of any commercial or financial relationships that could be construed as a potential conflict of interest.

Copyright (๐ 2015 Armstrong, Stone, Nicholls, Valderrama, Anderberg, Smedmark, Gautier, Naciri, Milne and Richardson. This is an open-access article distributed under the terms of the Creative Commons Attribution License (CC BY). The use, distribution or reproduction in other forums is permitted, provided the original author(s) or licensor are credited and that the original publication in this journal is cited, in accordance with accepted academic practice. No use, distribution or reproduction is permitted which does not comply with these terms. 